\title{
PERFORMANCE AND SUSTAINABILITY OF COMMERCIAL COOPERATIVES AND SOLE PROPRIETORSHIPS CITRUS FARMS IN MPUMALANGA PROVINCE, SOUTH AFRICA
}

\author{
Manenzhe, T. D., ${ }^{1}$ Zwane, E. M. ${ }^{2}$ and Van Niekerk, J. ${ }^{3}$
}

Correspondence author: T. D. Manenzhe. Email: tebogo.manenzhe@gmail.com

\begin{abstract}
Citrus farming is one of the specialised crops which need special attention in order to have a better product at the end of the value chain. Citrus crops that are well looked after produce good income while poor crops become costly to the farmer. Any suspicions of pests' damage may render the consignment for export to be turned down at the expense of a farmer. The objectives of this paper were to assess performance and sustainability between cooperatives and sole proprietorship citrus farms. The research also looked at the reasons as to why some farmers are more successful than others who farm in the same region with similar circumstances and challenges. This study compared the performance of commercial cooperatives and sole proprietorships of citrus farmers in Mpumalanga Province. A total of 40 farmers were interviewed in order to establish their scale of performance and contribution to sustainability. The findings revealed that the knowledge was a critical factor as they were found knowledgeable in citrus, such as management, business planning, packaging and marketing. It is recommended that the emerging citrus farmers should be exposed to acquisition of appropriate knowledge and skills if they have to perform better.
\end{abstract}

Keywords: Citrus farms, Cooperatives, Extension service, Performance, Sole proprietorship, Sustainability

\section{INTRODUCTION}

The production of citrus is considered as one of the specialised crop which needs special attention in order to have a better product at the end of the value chain. The citrus industry recognises this challenge and is making efforts to address product improvements. For example, the industry has alluded to competitiveness as a key for superior value for its customers and improved profits for the stakeholders in the value chain (Department of Agriculture, Forestry and Fisheries (DAFF), 2017). The industry even outlined that the productivity that is output efficiency, in relation to specific inputs with regards to human capital and natural resources, is the driving force in sustaining a competitive position. However, there are criticisms over the poor performance and weaker sustainability of some of the citrus enterprises in South Africa.

In South Africa, the performance and sustainability of privately owned citrus farms, as well as their sustainability, as compared to their counterparts both in land reform and state owned farms

\footnotetext{
${ }^{1} \mathrm{PhD}$ student, Department of Rural Development and Land Reform, University of the Free, Bloemfontein, South Africa, Email: tebogo.manenzhe@ gmail.com, ORCiD number 0000-0002-3160-9578

${ }^{2}$ Extension Professor, Centre for Rural Community Empowerment, Department of Agricultural Economics and Animal Production, University of Limpopo, Mankweng, South Africa, Email: zwanefrank@gmail.com, ORCiD number 0000-0002-5933-2910

${ }^{3}$ Director, Centre for Sustainable Agriculture, Rural Development and Extension, University of the Free State, Bloemfontein, South Africa, Email: vniekerkja@ufs.ac.za
} 
has created many questions. These farms are operating in the same vicinity under similar natural conditions. But, how do these privately owned farms use their opportunities and strengths to offset weaknesses and threats while their counterparts are tumbled-down by the same factors? Are the managers of privately owned farms just lucky or do they have some confidential tactics? The answer is that privately owned farms perform better and sustainably due to the fact that farm managers manage them better than land reform Communal Property Associations (CPAs), family orientated, and state owned farming enterprises. Nevertheless, what is the current performance and sustainability level of privately owned farms in Mpumalanga? This paper provides a profile of external and internal key fundamentals in the functional areas of the management capability, production, marketing, finance, procurement, personnel, risk management, as well as training of extensionists in citrus and logistics as significant in the advancements of better performance and sustainability.

According to Makhura (1992), the farmers that are in the high net-income category are considered to be performing well. The farm that reflects low net-income is considered to be performing poorly and is unsustainable. This viewpoint is related to the approach used to assess the farmer support programme (Development Bank of South Africa (DBSA), 2007), which determines whether farmers are net buyers or net sellers of food. Nieuwoudt, Henning and Jordaan (2017) describe a farm's performance as an assignment that is measured by how sustainable the farm is within its main markets and is determined by financial and non-financial measurements. In this regard, non-financial measurements include employee growth, job satisfaction, and self-sufficiency, amongst other things. Financial performance refers to minimisation of costs, maximisation of business growth, and the ability to increase profit.

The concept of sustainability has recently risen on top of land reform agenda. The policy for the Recapitalisation and Development Programme for the Department of Rural Development and Land Reform (DRDLR) (2013:7), 'The Comprehensive Rural Development Plan (CRDP)", was the first major land reform initiative that enhanced the awareness of land reform beneficiaries and other related stakeholders about "vibrant, equitable and sustainable rural communities" through social cohesion and inclusive development of the rural people and economies.

However, World Commission on Environment and Development (WCED, 1987) defines sustainability as a practice that meets the needs of the present generation without compromising the ability of the future generation to meet their own needs. The definition of sustainability in this regard emphasises the need for the present generation to ensure inter-generational equity by safeguarding the interests of future generations through maintaining the natural resources of this planet.

Performance and sustainability are regarded important elements of the modern farming enterprises. However, depending on a situation and requirements, enterprises' performance may have preference over sustainability. For instance, financial institutions and investors usually focus more on the overall picture of the enterprise's performance (Standard Bank Agribusiness South Africa (SBASA), 2013). Elements of financial performance are also included in a complete sustainability stewardship and vice versa. However, Norton (2004) as well as Van Reenen, Marais and Nel (2013) indicated that performance may be hampered by other elements of sustainability, more particularly, social and political pressure from the stakeholders that stand to lose from it, even if they may be regarded as the minority, they may 
apply pressure to derail performance. Similarly, a rapid expansion may also be hampered by biological factors and rising marginal costs on a limited area.

Researchers' reflections are that improved performance and sustainability in a farming enterprise are vehicles for keeping abreast with the ever-changing climate, technology, marketing, government policy, as well as meaningful decision making (Makhura et al., 2011). They are those tasks of farmers charged with the responsibility of, as SBASA (2013:1) would say, "having knowledge not only of the latest techniques for raising crops and farm animals but also of how to operate a farm business successfully". It is therefore no surprise that when poor performance and weaker sustainability takes place in the farm level, the blame lies squarely on the shoulders of the manager.

\section{METHODOLOGY AND MATERIALS}

As far as the methodology of this paper is concerned, a total of 20 cooperative farm managers as well as 20 sole proprietorship farms who acquired land without state assistance within all three citrus regional representatives of Mpumalanga Province, namely Nelspruit, Onderberg and Senwes, were sampled and interviewed. A proportionate simple sampling approach was adopted in this study which meant that each element of the survey population had a known and equal chance of being selected (Illowsky \& Dean, 2013). There were two strata, one stratum represented commercial cooperatives while the other represented sole proprietorships. Simple random sampling was applied in each stratum of the total population. A total of 40 respondents were reached from a survey population of the managers of 128 farmers who farm citrus under study in the $2017 / 18$ season. The majority of the respondents (50\% of sole proprietorship farms and $78 \%$ of cooperatives) were located in Ehlanzeni District in the Nelspruit region.

\subsection{Data collection}

There are numerous data collection methods, namely observation, face-to-face interviews, selfadministered methods, focus groups, and personal interviews (Matunhu, 2011). The data collection methods/techniques that were applied were predominantly face-to-face interviews. In terms of the data collection instruments, a structured questionnaire was utilised since this is mainly quantitative research. The collected data was captured and manipulated using statistical software. SPSS was then employed for the statistical analyses. With regards to ethical considerations, the respondents were assured that confidentiality would be assured and that they were not forced to participate in the study.

\section{RESULTS AND DISCUSSION}

\subsection{Cooperative and sole proprietorship farm composition}

This section focuses on the farm structure of two farming entities, namely cooperatives and sole proprietorship farms in Mpumalanga Province.

\subsubsection{Cooperatives}

In a personal interview with Naude (2018), the following definition for farming cooperatives was offered, "cooperative is a venture that is established by a group of farmers with a common goal, which is to achieve economic viability and societal acceptance in a collective manner by all members. It is a joint benefit to all farming members that seek to maximise profits for 
themselves and affiliated members". The cooperatives' operational structures enhancing performance and sustainability as well as maximisation of profit and societal acceptance in Mpumalanga Province are shown in Table 1.

Table 1: Farming cooperative composition

\begin{tabular}{|l|c|c|}
\hline \multicolumn{3}{|c|}{ Farming Cooperatives composition } \\
\hline Manager's gender & N & $\%$ \\
\hline Male & 20 & $100 \%$ \\
\hline Manager's age group & N & $\%$ \\
\hline $18-35$ & 1 & 5 \\
\hline $36-45$ & 1 & 5 \\
\hline $46-55$ & 11 & 55 \\
\hline 56 and older & 7 & 35 \\
\hline Total & $\mathbf{2 0}$ & $\mathbf{1 0 0}$ \\
\hline & & \\
\hline Number of farming members & $\mathbf{N}$ & $\%$ \\
\hline $2-5$ & 11 & 55 \\
\hline $6-10$ & 8 & 40 \\
\hline $11-15$ & 1 & 5 \\
\hline Total & $\mathbf{2 0}$ & $\mathbf{1 0 0}$ \\
\hline & & \\
\hline Number of women in executive positions & $\mathbf{N}$ & $\%$ \\
\hline $1-2$ & 4 & 20 \\
\hline $3-4$ & 4 & 20 \\
\hline None & 12 & 60 \\
\hline Total & $\mathbf{2 0}$ & $\mathbf{1 0 0}$ \\
\hline Highest level of education & $\mathbf{N}$ & $\%$ \\
\hline Com pleted secondary education (Matric) & 1 & 5 \\
\hline Obtained tertiary education & 19 & 95 \\
\hline Total & $\mathbf{2 0}$ & $\mathbf{1 0 0}$ \\
\hline
\end{tabular}

In Mpumalanga Province, the management of cooperative citrus farms was found to be dominated by males $(100 \%)$. The reason for this is because, in the previous dispensation, women and inequality was the order of the day. However, the new dispensation has instituted laws that provide equal opportunities in all aspects of the citizens of the country. Of these males, $55 \%$ were in the age category of $46-55$ years, $35 \%$ were older than 56 years, while $5 \%$ were youth (18-36 years), and a further $5 \%$ were of middle age (36-45 years). Furthermore, the majority of these farm managers $(55 \%)$ were managing cooperatives with the lowest affiliated members (2-5 members), followed by $40 \%$ of managers who manage cooperatives consisting of 6-10 members, while only $5 \%$ of the managers take care of cooperatives comprised of highest affiliated members of 11-15 members (Table 1). This clearly shows that a new approach is needed for agricultural development and extension to ensure that gender sensation programmes are introduced, and a full potential of youth and women is fully exploited. 
Almost all male farm managers obtained tertiary education (95\%), as compared to only $5 \%$ of farm managers who have only completed secondary education (Matric). However, in order to assess female's participation in other segments of farm management and decision making, the respondents were asked to provide the number of females in executive positions. The majority of females $(60 \%)$ were not part of the cooperatives' executive and thus, they were not participating in the cooperatives' decision making. Although, $40 \%$ of females were part of executives and decision making. This might be ascribed to the new legislation of the country, which empowers women (Table 1).

\subsubsection{Sole proprietorship farms}

As it was depicted in the methodology and materials, the majority of commercial farms in the Mpumalanga Province are run as sole proprietorships. In the case of these entities, they have to perform better and sustainably to maximise projected profit. During the interviews with Olwagen (2017), he explained that in the sole proprietorship farm, the decision making process is relatively short and the owner is entitled to the majority of the profit. The farm operational structure influencing performance and sustainability of these farms is depicted in Figure 1.

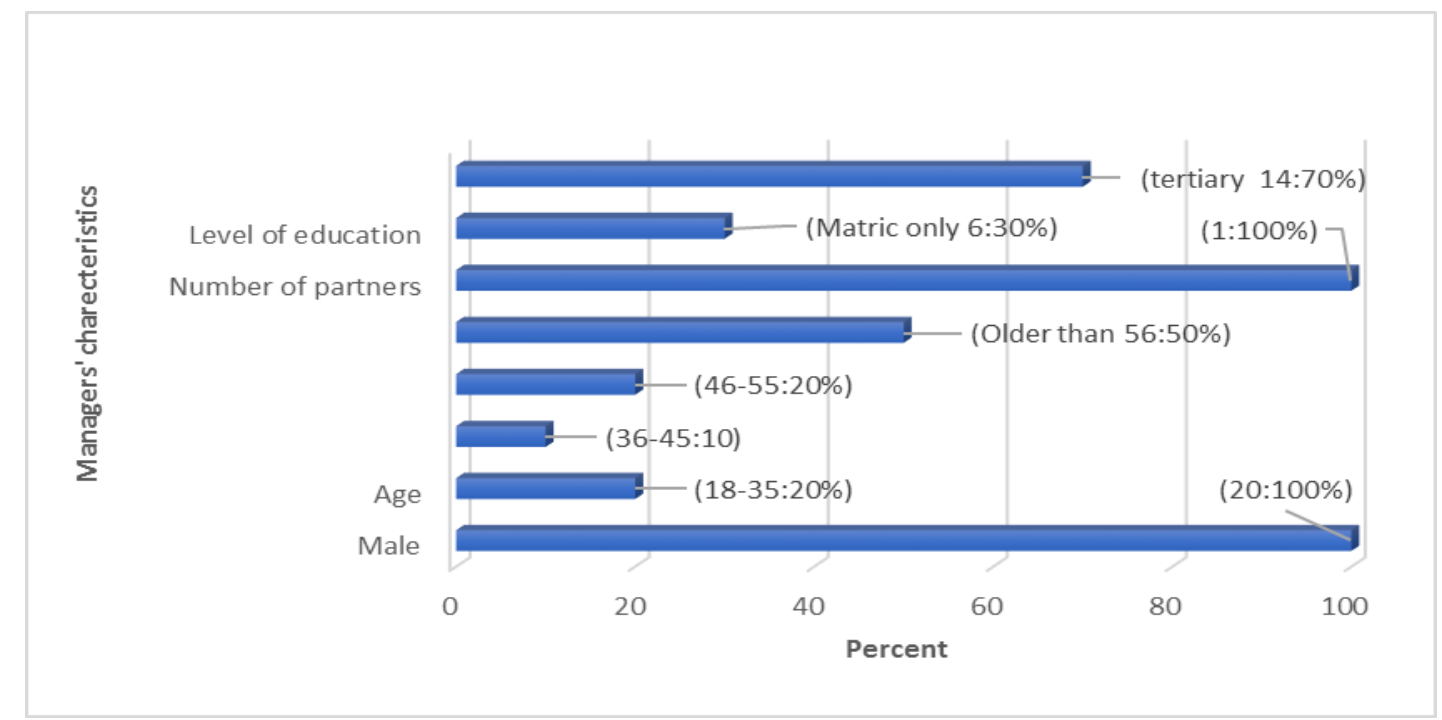

Figure 1: Farm structure of sole proprietors

The management of sole proprietor farms in the Mpumalanga Province are conquered by males $(100 \%)$, of which half are older than 56 years. The farm managers between the ages of 18 and 35 (youth) account for $20 \%$, while those of the middle age group (36-45 years) account for $10 \%$. Furthermore, those of the age group $46-55$ years account for $20 \%$ of the sole proprietor farms' managers. Furthermore, the majority of the managers $(70 \%)$ obtained tertiary education as compared to $30 \%$ that only completed grade 12 . In addition, these managers take care of sole proprietorships owned by only one family (Figure 1). Besides the positive results of the sustainability in the farms that are conquered by males, there should be an equal opportunity and recognition for women and youth in agriculture. The circumstances of women and youth in many agricultural projects are characterised by long hours of toil as they are underutilised, there is a lack of recognition, and often a negative attitude towards agriculture in general. 
S. Afr. J. Agric. Ext.

Vol. 48 No. 1, 2020: 70 - 83

http://dx.doi.org/10.17159/2413-3221/2020/v48n1a527
Manenzhe, Zwane \&

Van Niekerk

(License: CC BY 4.0)

\subsection{Closer analysis of farm's performance and sustainability}

The results in Table 1 and Figure 1 show that all cooperatives and sole proprietorship farms under this study are managed by males. Thus, this section provides an assessment of performance and sustainability, as well as the particular unique characteristics enhancing performance and sustainability. The unique characteristics are divided into two categories, namely unique farm operation and unique farm management model. As far as the first characteristic, it enhances performance and sustainability, whereas a close analysis of the second characteristic reveals that it focuses on management of human resources, farm business, and succession planning.

\subsubsection{Characteristics enhancing performance and sustainability}

WCED (1987) denotes sustainability as the need for the present generation to ensure intergenerational equity by safeguarding the interests of future generations through ensuring that the natural resources capital of this planet remains intact, meeting societal needs and economic viability.

However, Naude (2018), one of the managers interviewed, has this to say about enterprise performance and sustainability: "A farming enterprise just like any other business entity should at least operate in a sustainable way to ensure better performance. If the farm is not operating well, such a farm cannot maintain a good performance over the long period". Reputable and sustainable farming enterprise firstly needs good investment in principled operators. It is the writer's observations that a farm that seeks to perform better and remains sustainable should begin by carefully employing an operator with the particular technical knowledge and general management skills. The particular characteristics of the farm operators are depicted in Table 2.

Table 2: Particular operator's characteristics

\begin{tabular}{|c|c|c|c|c|}
\hline \multirow{2}{*}{\begin{tabular}{|l} 
Particular operator's characteristics \\
Prior farm management experience \\
\end{tabular}} & \multicolumn{2}{|c|}{ Cooperative } & \multicolumn{2}{|c|}{ Sole proprietors } \\
\hline & Yes (\%) & No (\%) & Yes (\%) & No (\%) \\
\hline I managed a farming entetrprise before & 100 & - & 95 & 5 \\
\hline Performance and sustainability prior current manager & Yes (\%) & No (\%) & Yes (\%) & No (\%) \\
\hline This enterprise was performing good and sustainable prior & 95 & 5 & 95 & 5 \\
\hline Number of years managing prior enterprises & $\mathrm{N}$ & $\%$ & $\mathrm{~N}$ & $\%$ \\
\hline I previously managed an enterprise for $3-5$ years & 4 & 20 & 5 & 26 \\
\hline I previously managed an enterprise for $5-8$ years & 10 & 50 & 7 & 37 \\
\hline I previously managed an enterprise for more than 8 years & 6 & 30 & 7 & 37 \\
\hline Previous management model within the current enterprise & $\mathrm{N}$ & $\%$ & $\mathrm{~N}$ & $\%$ \\
\hline The enterprise was managed by sole families & 19 & 95 & 19 & 95 \\
\hline The enterprise was managed by state entity & 1 & 5 & 1 & 5 \\
\hline
\end{tabular}


The majority of cooperatives and sole proprietorship farms were previously owned and managed by sole families (95\%), whereas $5 \%$ of the cooperatives and sole farms were previously owned and managed by the state. These farms were performing well and sustainably, as reported by $95 \%$ of the participants, while $5 \%$ of these farms were not performing well and were unsustainable (Table 2).

Table 2 further shows that these farming enterprises have invested largely in employing principled operators with the particular technical knowledge and general management skills. All cooperative farms (100\%) employed farm managers who previously managed a farming enterprise and most managers had a minimum of 5-8 years of relevant farm management experience (50\%), while other managers had more than 8 years $(30 \%)$, and the other managers with the least number of years in managing a farm accounts for $20 \%$.

Similarly, sole farms also invested heavily in technical and skilled operators (95\%) as compared to only 5\% which are not investing deeply in the aforementioned characteristics. Furthermore, $95 \%$ of these farmers have recruited managers with the most combined minimum of 5 to more than 8 years relevant farm management experience $(74 \%)$, while 5 farmers had recruited managers with the least experience of 3-5 years, accounting for $26 \%$ of the sample (Table 2). It is clear that these farming enterprises are reputable and sustainable due to the fact that good investment is made in recruiting principled operators with particular technical knowledge and general management skills.

\subsection{Farm management model}

\subsubsection{Analysis of human resource management model and enterprise}

In South Africa, it is believed that management of farming enterprises has changed radically in the past decade due to factors such as political, economic, social-cultural, technological changes, environmental awareness, and legislation (DAFF, 2017; Goldbalt, 2012; Makhura et al, 2011; Wood, 2013). The current researchers' conviction is that these factors are proven to have critical impact on the management model as well as performance and sustainability of farming enterprises.

Naude (2018) and Olwagen (2017), based on their experience and observations, acknowledged that "The farm managers are now even expected to have good interpersonal skills to be able to manage human resources accordingly and farms sustainably to ensure continuous performance". However, for these managers to be held accountable, it is the researchers' assumption that there should be a depicted model or roadmap for successfully employing and managing human resources. Table 3 illustrates the analysis of the human resource management model applied by cooperatives and sole proprietorship farms, as well as key factors supplementing the model. 
Table 3: Analysis of human resource management and supporting systems

\begin{tabular}{|c|c|c|c|c|}
\hline \multicolumn{5}{|c|}{ Farm human resouce management model and supporting systems } \\
\hline \multirow{2}{*}{ Local community members employed } & \multicolumn{2}{|c|}{ Previous model } & \multicolumn{2}{|c|}{ Current model } \\
\hline & $\mathrm{N}$ & $\%$ & $\mathrm{~N}$ & $\%$ \\
\hline Cooperatives & 20 & 100 & 20 & 100 \\
\hline Sole families & 20 & 100 & 20 & 100 \\
\hline \multirow[t]{2}{*}{ Key systems sustaining the enterprises } & \multicolumn{2}{|c|}{ Cooperatives } & \multicolumn{2}{|c|}{ Sole families } \\
\hline & $\mathrm{N}$ & $\%$ & $\mathrm{~N}$ & $\%$ \\
\hline Management model & 14 & 74 & 10 & 51 \\
\hline Support & 4 & 18 & 2 & 8 \\
\hline Ability to management change \& innovation & 2 & 8 & 8 & 41 \\
\hline
\end{tabular}

As seen in Table 3, the way in which both cooperatives and sole proprietorship farms employ and manage human resources to improve and maintain performance has not changed, irrespective of changes in the factors of agricultural production and the current uncertain political climate in which these farming enterprises have to perform. As far as employee recruitment and management is concerned, both cooperatives and sole proprietorships were previously, and are still currently employing labour force from their local villages (100\%).

Furthermore, recruitment can also be done from within the family itself or from relatives/extended family members. Either way, it is always good to bear in mind the returns of recruiting both family and community members. The human resource management model involves labour relations to ensure that good labour relations are maintained at all times. However, for any sectional management model to be successful, supporting systems must be in place. Without proper supporting systems, efforts of a sectional model will in future be of no value (Van Reenen et al, 2013). The key supporting systems as set out in Table 3 are discussed.

The whole farm management model was found to be a key catalyst for good implementation of cooperatives $(74 \%)$ and sole families' $(51 \%)$ human resources management model. The majority of sole families $(41 \%)$ used their strategies for dealing with change and innovation to supplement their human resources model as compared to $8 \%$ of cooperative farms. Furthermore, a key factor to some of these farmer's cooperatives $(18 \%)$ and sole families $(8 \%)$ was the support from their principals and investors. The key system supporting the human resources model to remain relevant at all times and to add value to the performance and sustainability of cooperatives and sole families is a farm management model, which is of particular concern in this study.

\subsection{Farm business and succession planning}

Farm business and succession plans are regarded as the most vital aspects of the modern farm business (Ntshangase et al, 2016; SBASA, 2013). However, in the present period of high input prices, technical economic recessions, shortage of capital, and high interest rates and Value Added Taxes (VAT), it is the researchers' submission that a business plan has a large preference over succession plan. Similarly, in a personal interview with Mogoru (2017), it was stated that in South Africa, the majority (if not all) of financial lenders and investors usually pay more attention to the affordability and financial projections in the business plan, even 
though the components of business plans are included in the succession plan and vice versa. This section provides a summary and perspective of both business and succession planning.

A business plan is a roadmap that describes a farm business, its products or services, the way in which the farm business will generate income, management, financing, operations model, and other details that are essential to both operation and performance (SBASA, 2013). The new entrants in farming develop a business plan as part of the start-up process while existing farm businesses often write the business plan when changing direction or strategy. Furthermore, experience has shown that both new entrants and existing business plans mirror the farm business for at least the first three to five years. For instance, a Champagne citrus farm business plan by Andrews and Mavimbela (2011:20-21), aiming at the strategy of maximising production and profit, has mirrored the plans for a five year period as follows, "To improve production by rehabilitating the existing orchards in order that extended benefits will accrue from current tree and replanting programmes".

The researchers' observation is that a succession plan is developed to provide a clear succession planning measure that will assist the employees and farm business on career management and managers on their management roles and responsibilities. It also assists in the facilitation of deployment and retention of high performing managers and employees through effective career planning in line with the farm business development programmes or plan, and maintains and enhances the particular farm knowledge. Succession plan is also vital since it creates a pool of suitably competent and high performing employees that can be eligible to fill vacant positions which may require specific scarce, critical, and high risk skills such as management positions (SBASA, 2013). The preference of business plan over succession plan and vice versa is illustrated in Figure 2.

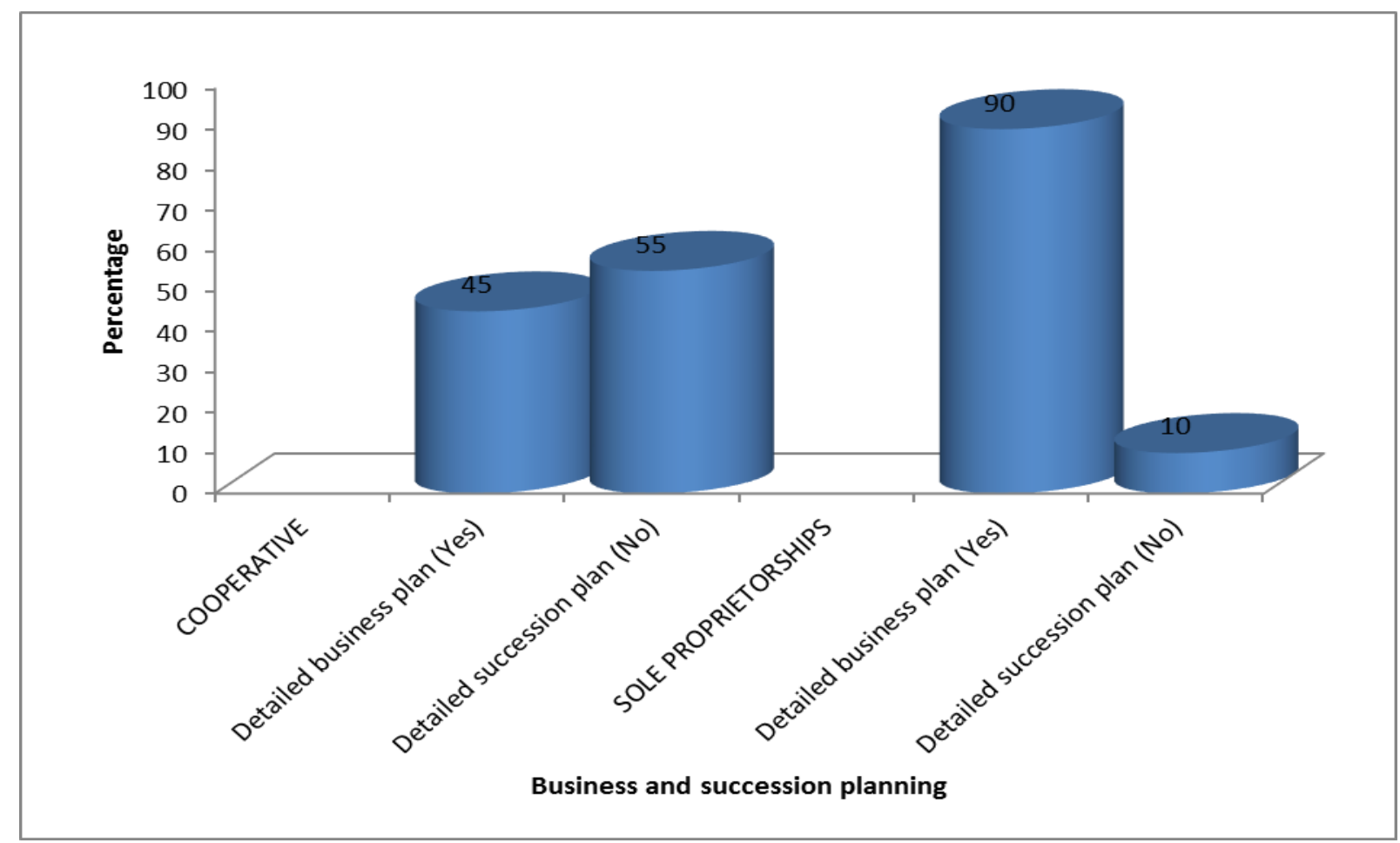

Figure 2: Preference of business and succession plan

Both long existing cooperatives and sole proprietorship farming businesses have a farm business plan. This is encouraging to see that these farming businesses seek to change direction 
or strategy to curb the ever-changing farming factors such as changes in the characteristics of farming production, as well as the economic and political climate.

According to Figure 2, 45\% of cooperatives and $90 \%$ of sole proprietors have detailed business plans, while $55 \%$ of cooperatives as compared to only $10 \%$ of sole proprietors operate without a succession plan. It is clear that cooperative farm businesses in Mpumalanga Province operate without clear succession planning that would have otherwise assisted in terms of facilitating the deployment and retention of high performing managers and employees, and maintain and enhance the particular farm business culture and knowledge.

\subsection{Internal and external issues affecting performance and sustainability}

The earlier section has looked at the performance and sustainability of cooperatives and sole proprietorship farming business, especially within the context of farm compositions/structure and unique characteristics (farm operations and farm management model). This was done by scanning and analysing current farm managers' age and experience in managing similar farming businesses, as well as previous and current human resource management models and supporting systems. However, this section evaluates and distils the information captured in the above section into a critique reflecting these farming businesses' primary strengths, weaknesses, opportunities and threats, better known as the SWOT analysis. According to (Wood, 2013), SWOT analysis is the process of looking at the inside and outside of the farming enterprise. In addition, this study conducts a SWOT analysis of current or potential pitfalls to clarify the competitive situation. Furthermore, the objective of this paper was to assess performance and sustainability of cooperative and sole proprietorship citrus farms, find key strengths and opportunities that assist these farmers to prosper more than others who farm in the same region under similar circumstances, and find out threats and weaknesses that crimple some farmers as compared to other farmers.

\subsubsection{Identifying strengths, weaknesses, opportunities and threats (SWOT)}

The internal issues such as the way in which these farming businesses fulfil their mission, serve customers, and compete in the marketplace is identified and analysed in this section. This includes issues such as the farm's market resources/infrastructure and capabilities, current offerings and quality, business relationships, and other key issues. The issues to be identified herein are the key instrumentals in the way that these farming businesses perform better and sustainably, serve both local and international customers. These key issues are just as important in contributing to the farm's strengths and weaknesses in using the current management model to deal with opportunities and threats.

According to the SWOT analysis in Table 4, the cooperatives and sole families' farmers in Mpumalanga Province, like most land reform and emerging farmers in the province, have less weaknesses and face fewer threats. However, most of the farming factors enhancing performance and sustainability within cooperatives and sole families in the Mpumalanga Province stem from (i) access to infrastructure (100\%), (ii) good relationship with suppliers and customers (90\%), (iii) meeting of all the required operating standards (80\%), (iv) good product quality (100\%), and (v) adequate farming knowledge and skills (100\%). 


\section{Table 4: Analysis of SWOT factors enhancing performance and sustainability}

\begin{tabular}{|c|c|c|c|c|c|}
\hline Farm's strengths & Cooperatives & Families & Farm's weaknesses & Cooperatives & Families \\
\hline & $100 \%$ & $100 \%$ & & $100 \%$ & $85 \%$ \\
\hline - Good quality & $100 \%$ & $100 \%$ & traditional markets & & \\
\hline $\begin{array}{l}\text { - Good relationship with } \\
\text { suppliers and customers }\end{array}$ & $90 \%$ & $100 \%$ & - High inputs costs & $100 \%$ & $100 \%$ \\
\hline $\begin{array}{l}\text { - Meeting all required operating } \\
\text { standards }\end{array}$ & $80 \%$ & $100 \%$ & & & \\
\hline - Farming skills \& knowledge & $100 \%$ & $90 \%$ & & & \\
\hline Farm's opportunities & & & Farm's Threats & & \\
\hline - Accessing new markets & $100 \%$ & $100 \%$ & - Shortage of water & $100 \%$ & $100 \%$ \\
\hline - High demand of produce & $100 \%$ & $100 \%$ & - Increased protectionisms & $55 \%$ & $85 \%$ \\
\hline - To grow local market shares & $100 \%$ & $95 \%$ & & & \\
\hline
\end{tabular}

These factors also leverage the increased protectionisms by international markets. Although several other factors might contribute towards mitigating increased protectionism, it is indirectly related to poor strengths (i.e. poor product quality, failure to meet the required standards, and inadequate farming skills and knowledge), as well as the inability of farm managers to implement the fixed standards. The increased protectionisms hold several threats for citrus farmers' performance and sustainability in the Mpumalanga Province, and are one of the main reasons for the collapse of reputable farms. Within the current economic climate, the collapse of high reputable farms holds severe consequences for both the development and commercial legs of the sector, with a potential decline in productivity and local economy's growth.

The weakness by these farmers is the inability to be creative in their marketing strategies. All of the farmer cooperatives $(100 \%)$ and $80 \%$ of sole families rely heavily on their traditional markets. This relates especially to current global agriculture, and the political and economic environment faced by producers. Hence, the creativity of these producers relates directly to the country's trades bilateral agreements, which can be regarded as one of the prerequisites for success in modern day agriculture (DAFF, 2017). Besides the threat of increased protectionisms by international markets, the lack of capacity and knowledge within government institutions poses additional stumbling blocks for performance and sustainability, especially with regards to the successful implementation and management of trades' bilateral agreements (i.e. tariffs and meeting Good Agricultural Practice (Global.G.A.P) certifications). However, the cooperatives and sole families (i) have access to new markets (100\%), (ii) their products are in high demand (100\%), and (iii) there is a huge capability of growing in local market shares, particularly for cooperatives (100\%), as compared to $95 \%$ for sole families.

Moreover, a lack of commitment on the part of various government intuitions has resulted in poor farmer support. This relates directly to problems that are experienced by farmers with product affected by "black spot" and "codling moths". The problems in governmental projects 
in several instances originate from officials not being properly made aware of the consequences of the local economy or competent to execute their respective roles and responsibilities.

Another factor that poses a stumbling block for performance and sustainability in these farms in the Mpumalanga Province, unrelated to increased protectionisms, pertains to the possibility of shortage of water and high inputs costs as stated by $100 \%$ of both cooperatives and family farmers. Similarly, the entire Mpumalanga Province faces water shortages due to a lack of water resources and general decrease in water quality and quantity over the past few years. The water shortages result from a climate change, while high input costs relate to an unstable economy. The consequence of these quarrels generally results in farmers failing to procure farming inputs and worker retrenchments, which effectively puts local people out of work and farmlands out of production.

\section{AGRICULTURAL EXTENSION IMPLICATIONS FOR THE CITRUS FARMERS IN SOUTH AFRICA}

This study has portrayed that performance and sustainability are key elements in the viability of the cooperatives and sole proprietorship farms. Due to good performance and sustainability, these farms have managed to offset the ever-increasing protectionisms from the international markets, water deficiency and high input costs. These farmers also did well in producing a better product at the end of the value chain, and this has brought a good income to the farmers. Otherwise, if these farms had performed poorly and were unsustainable, the consignment for export would have been turned down at their expense.

Part of the implication of this study indicates that there is a weakness in having human resources such as extensionists who are trained in citrus farming. The study also pointed out a shy commitment from government agencies and institutions providing agricultural extension on the provision of extensionists trained in citrus farming. Knowledgeable advisors play a role in making citrus farms sustainable. It is no surprise that the Citrus Growers Association (CGA) has signed a memorandum of understanding (MoU) with the provincial departments of agriculture and rural development agreeing that the departments should provide government extension personnel who are trained as citrus specialists to provide support to growers (DAFF, 2017).

\section{CONCLUSION}

This study has examined the performance and sustainability of citrus farming cooperatives and sole proprietorships in Mpumalanga Province of South Africa. This experience arose in the context of poor performance and unsustainability of land reform citrus farming enterprises. It shows how cooperative and sole proprietorship farms were previously, and are still currently managed by managers whose experience in farming is large enough. Performance and sustainability of these enterprises have not changed in some ways, yet also demonstrate beneficial levels of improvement and continuity.

Overall, this study revealed that the business models promoted as part of both cooperatives and sole proprietors have succeeded in producing sustainable enterprises or distributing benefits to the shareholders. From Mpumalanga's perspective, the assessment of performance and sustainability of cooperatives and sole proprietorships appear to be largely positive. Enough material progress has been made in any of the cases outlined here to conclude that these types 
of farming enterprises are performing well, or are delivering sustainable benefits to the shareholders over time.

Despite a discouraging period, including land reform and unfavourable conditions for production as a result of climate change, it is clear that some fundamental progress has been made in the design and implementation of these enterprises. On the cooperative side, a detailed business plan and management model are adhered to, and the mangers that are employed have farming skills and knowledge, and cooperatives are able to deal with increased protectionisms. On the sole proprietors' side, little firm commitments have been made regarding investment on employing managers with farming skills and knowledge, tackling the ever-increasing international protectionisms, and putting in place a detailed business plan. It is concluded that cooperatives perform much better and are more sustainable than the sole proprietors' farms. As it has been revealed that Mpumalanga's cooperatives and sole proprietors are doing well using their ancient model, these models are also crucial to the future. Mpumalanga is increasingly becoming a land reform beneficiaries' farming industry.

Arising from this study, the following recommendations are offered. Firstly, functionality within government institutions needs to be revived, as it serves as the foundation from which most of the factors hindering farmers' performance and sustainability need to be resolved. Secondly, government support is needed to boost existing citrus farmers as well as to motivate the establishment of new initiatives to address current and emerging problems in order to enhance the performance and sustainability of the sector in provincial, national and global markets. It is further recommended that the department should prioritise training dedicated extensionists who will service the Black citrus growers. This approach will promote sustainability of citrus growers. Departments such as the Department of Agriculture, Department of International Relations, Trade and Industry, as well as marketing channels should place high attention on cooperatives and sole proprietorship farmers' basic capabilities. The government extension policies and programmes should be determined based on extension officers and famers' abilities, as well as international needs and standards. Furthermore, bilateral agreements should be arranged on time to provide extension officers with adequate time to familiarise themselves with the agreements, and farmers to prepare and comply.

\section{REFERENCES}

ANDREWS, B. \& MAVIMBELA, R., 2011. Champagne citrus farm business plan. Nelspruit, South Africa.

DEPARTMENT OF AGRICULTURE, FORESTRY \& FISHERIES (DAFF), 2017. A profile of the South African citrus market value chain. Pretoria, South Africa.

DEPARTMENT OF RURAL DEVELOPMENT AND LAND REFORM (DRDLR), 2013. Policy for the Recapitalization and Development of the Department of Rural Development and Land Reform. Pretoria, South Africa.

DEVELOPMENT BANK OF SOUTH AFRICA, 2007. Development Indicators of Emerging Farmers in South Africa. Unpublished DBSA research report.

GOLDBALT, A., 2012. Agriculture: Facts \& trends. South Africa. Available from: http://awsassets.wwf.org.za/downloads/facts_brochure_mockup_04_b.pdf

ILLOWSKY, B. \& DEAN, S., 2013. Collaborative Statistics. Available from: http://cnx.org/content/col10522/1.40/Pdf 
MAKHURA, M.T., 1992. Farmer selection criteria for settlement in agricultural land: Attributes of successful versus unsuccessful farmers. Research Proposal, Pennsylvania State University.

MAKHURA, M.N., MDA, M., MARAIS, P. \& JACOBS, J., 2011. Addressing challenges of addressing emerging farmers. Land Bank Report. Pretoria, South Africa.

MATUNHU, J., 2011. Rural agriculture for rural development: Rural agriculture for rural development in South Africa. Saarbrucken: Lap Lambert Academic Publishing.

MOGORU, C., 2017. Personal interview. Thekwane Citrus Farm manager. Nelspruit, $11 / 09 / 2017$.

NAUDE, C., 2018. Personal interview. Malelane Citrus Cooperative manager. Nelspruit, $31 / 10 / 2018$.

NIEUWOUDT, S., HENNING, J.I.F. \& JORDAAN, H., 2017. Entrepreneurial competencies and financial performance of farmers in South Africa. S. Afr. J. Econ. Manag., 20(1):13 .

NORTON, R., 2004. Agricultural development policy: Concepts and experiences. Chichester: John Wiley \& Son Ltd.

NTSHANGASE, W.M., NGIBA, S.C., VAN NIEKERK, J.A. \& ZWANE, E.M., 2016. The impact of succession planning on the sustainability of cane production by small scale cane growers in North Coast of KwaZulu Natal, South Africa. S. Afr. J. Agric. Ext., 44(1):50-58.

OLWAGEN, H., 2017. Personal interview. LA Visagie and Seuns Farm manager. Karino, 08/11/2017.

STANDARD BANK AGRIBUSINESS SOUTH AFRICA (SBASA), 2013. Finance and farm management. 5th ed. Johannesburg: The Standard Bank of South Africa Limited.

VAN REENEN, M.J., MARAIS, A.K. \& NEL, P.S., 2013. Farm management: Financial, investment and human resources management, 12th ed. Pretoria: Van Schaik Publishers.

WOOD, M.B., 2013. Essential guide to marketing planning. 3rd ed. Prentice Hall: Pearson Publishing.

WORLD COMMISSION ON ENVIRONMENT AND DEVELOPMENT (WCED), 1987. Our common future. New Delhi: Oxford University Press. 
